\title{
Towards a Better Perspective on Elderly Care: A Case Study
}

\section{Takahiro Miyo}

ISSN: 2311-8636 (Print)

ISSN: 2312-2021 (Online)

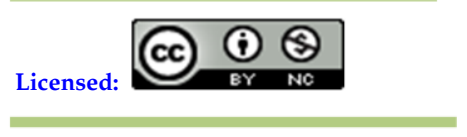

Source of Support: Nil

No Conflict of Interest: Declared

Email for correspondence: *

*takahiro_miyo@hotmail.com

Methodology: I conducted semi-structured interviews with one married elderly couple, who had had various experiences of caring for their old parents. While recalling their old days when they used to care for their parents, they were also asked to envisage their own future lives, in which they will need care from others.

Results: Based on qualitative descriptive analyses of their interview data, a highly individual care-plan emerged for each study participant. It was suggested that the ways their old parents lived in their later lives, as well as their experiences of caring for them, were strongly reflected in their own future care-plans.

Conclusions: In order to envisage one's realistic future in which he/she needs care from others, concrete experience of relevance may be necessary, which would make it possible to discuss frequently his/her own future life with family, friends, and medical providers.

Keywords: Care-plans, Elderly care, Population aging, Qualitative descriptive approach, Wellbeing

\section{INTRODUCTION}

The percentage of the elderly is increasing on a worldwide scale, and Japan has the highest in the world; in 2065, the percentage of the elderly is anticipated to reach $38.4 \%$, in which 1 out of 2.6 people would be 65 years old or over (Cabinet Office Japan, FY 2017). The number of people requiring long-term care is increasing among the elderly; in particular, the number of the elderly with dementia is estimated to go on increasing steadily in the future (the elderly with dementia in Japan are anticipated to be 8.50 11.54 million people in 2060; Cabinet Office Japan, FY 2017). Although it is a worldwide tendency that the percentage of the elderly is increasing, the difficulties that aging countries such as Japan are now or will be faced with seem more serious to tackle, because such populations are decreasing as well as aging. Using some evolutionary genetic models, it was suggested that under these difficult demographic situations, we should consider how we could derive benefits from the 
elderly as much as we can as well as how we could manage an enormous cost of elderly care as neatly as we can (Miyo, 2017, 2020).

In 1990s, the traditional system of caring for the elderly in Japan, which usually relied heavily upon daughters-in-law and spouses, was widely taken as inappropriate in dealing with an increasing number of the elderly who need long-term care; there were many tragedies in caring for the elderly, including maltreatment and neglect by caregivers, who were usually daughters-in-law and spouses exhausted by the effort of elderly care (Matsuda, 2009). In addition, social hospitalization was a serious social matter at that time in Japan, in which many elderly people were hospitalized and kept staying in hospitals, because their families were unable to or reluctant to take care of their old parents, which resulted in the increment in medical expenditure (Iwagami and Tamiya, 2019). As a consequence, the necessity for elderly care to be socialized occurred naturally among the public, and the Long-Term Care Insurance (LTCI) System was introduced in 2000 (Matsuda, 2009; Iwagami and Tamiya, 2019).

In Japan, a new professional person called "a long-term care support specialist" (hereafter care-manager) has been introduced, who is responsible for organizing and managing care and social services for each user (Watanabe et al., 2013; Hirakawa, 2016). The care-manager is defined in the Long-Term Care Insurance Act as a person who provides consultation to persons requiring long-term care, etc., and communicates with and coordinates municipalities, long-term care support service providers, etc. (Long-Term Care Insurance Act, $\quad$ Article 7-5; http:/ / www.japanlawtranslations.go.jp/law/detail/?id=94\&vm=\&re=\&new=1; accessed on August 7,2020). In other words, the major roles care-managers play in the LTCI system are to assess care needs and health problems of elderly people and their families, to perform care planning for individual users and to coordinate care support service providers, and to monitor and evaluate users' health conditions and appropriateness of care supports and services regularly (Hirakawa, 2016; Ito et al., 2018). The LTCI System in Japan covers longterm care and social services for the elderly aged 65 years and over, as well as those aged between 40 and 64 years who enrolled in medical insurance and suffer from one of the specified diseases (Ministry of Health, Labor and Welfare, 2016; Tokyo Metropolitan Government, 2018). Under the LTCI System, the elderly who need long-term care support for daily life would receive assistance from a care-manager for their use of care services and management of those services; care-managers are expected to play a central role in developing an individual care-plan for each user, which needs to be reviewed regularly, based on the user's conditions (Watanabe et al., 2013; Hirakawa, 2016). If the LTCI System is implemented ideally in Japan, the elderly may be able to live their later lives happily, and there might be no problem at all; however, there seem to be serious difficulties at present. For example, one qualitative study examined barriers to achieving high-quality, community-based integrated dementia care in Japan, and found problems, including little attention given to patient wishes and lack of time and space for providing patients with high-quality care (Hirakawa et al., 2017). Taking into account the fact that care staff are not sufficient in numbers in Japan (Cabinet Office Japan, FY 2017), the situation in which little attention has been given to patient wishes may not be rare in caring for the elderly, especially those with dementia, in Japan.

In order to illustrate one of the difficulties in caring for elderly people in Japan, let us consider the situation, where we are making a care-plan for a user suffering from dementia. I have some experience in caring for the elderly as a certified care-worker, and also making 
some care-plans as a certified care-manager for a little while. In the process of making plans, of course, we have been trained as a care-manager to recognize the needs of users and to attempt to realize their lives which users wish to live, utilizing various long-term care services and social resources. However, when I actually made care-plans for users, I always wondered how much I could understand the users, especially in cases where they suffered from dementia, as a care-manager or even as one of others. We sometimes get in trouble, even when we can communicate easily and effectively with others, such as parents and children, husbands and wives, friends and so on. If so, how much could care-managers understand elderly users, especially those with dementia? I had been always suffering from this question, since I was in the training program for care-managers and when I was actually making care-plans for elderly users.

In western countries, such as the United Kingdom and the United States of America, advance care planning (hereafter ACP) has been practised. The aim of ACP is to help patients establish decisions about future care that come into effect especially when their mental capacities are lost (Mullick et al., 2013). Although ACP is supported by patients as well as doctors, older people having ACP are few, because of lack of knowledge, older people's assumptions that family and carers know and will follow their preferences, clinicians' discomfort, and so on (Malcomson and Bisbee, 2009; Aw et al., 2012). In Japan, there is a guideline which supports decision-making of patients for their end-of-life care, but there is no legal establishment of mandatory advance directives or legislation which supports ACP, so that the prevalence of advance directives was very low (Hirayama et al., 2017; Miyashita et al., 2019). However, ACP could be valuable especially in end-of-life care, if discussions are routinely taken place between patients, carers, and health-care professionals (Aw et al., 2012).

Although it may seem to be similar to ACP, this study attempted to consider how elderly people in good condition could imagine their future when they need to be cared for by others. Because they are still in good condition, this procedure is neither within the LTCI system nor within the medical treatment framework. It may be natural that in the situations where we are forced to make decisions, options from which we could choose may be limited (Malcomson and Bisbee, 2009), so that I would like to focus on the earlier stages of their later lives, in which they would be still in good condition, rather than the last or end-of-life stages, in order for them to have more freedom of choice. In other words, in this study, I would like to focus on the perspective towards a better well-being of the elderly, even though they need care and support from others, rather than the dying process.

Even though we collect as much information concerning a user as possible, how much could we understand him/her? Eventually, the person who knows the user best is him-/herself. If so, even though we make care-plans as care-managers, those plans are based on representations of users which are perceived through eyes and ears of care-managers and interpreted by them, so that if things do not go well, the care-plans are nothing more than self-satisfaction of care-managers, not for the users. If so, may the best care-plan for each user be that made by him-/herself while he/she is in good condition? If help from others becomes necessary for everyday lives due to diseases or disabilities, or if they suffer from dementia, lives desired by elderly users could be lost, or at best, they have to live their lives which others imagine to be desired by them. Therefore, it is necessary for the elderly themselves to consider and imagine how they wish to live their later lives, how they would like to live if they need care from others, what kind of world they might live if they suffer from dementia, and so on, while they are in good condition. However, it would be difficult 
for the elderly in good condition to imagine these situations and to answer the aforementioned questions, just because they are in good condition, so that they do not need to consider these situations. For example, it was suggested that not only do people with diseases or disabilities tend to misreport their well-being, but healthy people also mispredict the emotional influence that diseases and disabilities are likely to have on their lives, putting them at risk for making wrong decisions (Ubel et al., 2005). It was also suggested that preferences for medical treatment may change over time (for example, become more willing at some times but less willing at other times, or vice versa), not only in patients with inconsistent health states but also in patients with consistent health states, so that the ACP process would be strengthened if their preferences could be re-evaluated over time (Fried et al., 2007; Fried and O'Leary, 2008). In addition, it was suggested that people with dementia found it difficult to consider their future selves and potential burdens which their illness may impose upon their families, so that discussions with clinicians concerning preferences and wishes are the most valuable in the ACP process for people with dementia (Dening et al., 2013).

Because experiences of older people and their caregivers are usually highly individual, their experiences would often be inconsistent with the traditional approaches. Based on the actual experiences of older patients at the end of life and their caregivers, new approaches towards ACP were suggested (Fried and O'Leary, 2008). In fact, a qualitative study examining the attitudes towards end-of-life care and advance directives among Japanese citizens demonstrated that experiences of caring for people in the end-of-life stage had positive and negative influences on their attitudes (Hirayama et al, 2017). Similarly, individuals' experiences of caring for important persons could help envisage their own future lives. In this study, I attempted to find out how we could make the elderly in good condition imagine their later lives in which they need care from others. To do this, I conducted semi-structured interviews with one married elderly couple to recall their old days when they used to take care of their own old parents. While recalling their old days when they used to care for their old parents, they were also asked to imagine their own future lives where they might need care from others. The goal of this study was to have the elderly in good condition make their own care-plans through recalling their old days.

\section{Methodology}

\section{Design}

It would be more desirable that the elderly get used to considering their own later lives in need of care from others and their own care-plans to some extent, while they are in good condition. Then it would become important that they discuss and share their own ideas and care-plans among family members. However, it is quite natural that it is difficult for people in good condition to imagine the situations in which care from others is necessary and to answer those questions concerning how to live and what to do, if care from others is in need. Therefore, I asked the participants to recall their parents and their old days when they used to care for their parents, because it was thought that their old memories may provide clues to imagining their own later lives and their being cared for by others. The ultimate goal of this study was to make their care-plans with the assistance of their own memories. To do this, a qualitative descriptive approach was employed because it is suitable to describe everyday events in their own terms (Sandelowski 2000; Gregg et al., 2013).

\section{Study Participants}


In this study, I focused on one old married couple (hereafter referred to as Mr. and Mrs. A), because I had some experiences of caring for their old parents, so that I knew they had had various kinds and amounts of experiences of caring for their old parents, which was the most suited for this study. In addition, I would make their care-plans in the future when they need care support, so that they are suited from the standpoint of the continuity of caremanagement for them.

Mr. A was in his early-80's when he participated in this study. His father passed away in hospital about 45 years ago, when Mr. A was busy at work. His mother suffered from dementia and passed away at a nursing home for the elderly, several years after Mr. and Mrs. A took care of her.

Mrs. A was in her late-70's when she participated in this research. Her father had been unconscious and bedridden in hospital for several years after brain tumor surgery and passed away about 40 years ago. Her mother had lived alone for a long time, but she decided to be hospitalized because of difficulties in performing daily activities (social hospitalization). She passed away in hospital about 20 years ago.

At the time when Mr. and Mrs. A participated in this study, they both belonged to Category 1 insured individuals under the LTCI system in Japan (those aged 65 and over), but they had no need for any care support and performed daily activities by themselves. Under the condition in which their personal information will be kept strictly confidential, they kindly accepted to participate in this study.

Sample Sizes in This Study

Paying attention to individuals' lives and their life courses should make it possible to consider in detail how we should and could care for them, which may lead to high quality of care (Kuroe and Fujisawa, 2016). The goal of this study was to have the elderly in good condition envisage their own care-plans by means of recalling their old days when they used to care for their old parents. Because I would like to focus on the process of making their own care-plans through their old memories, the case study approach should be adopted for each participant. From the standpoint of the concept of information power (Malterud et al., 2016), the least amount of participants would be sufficient for this study, because the aspects on which the focus of this study was placed were quite personal. However, generalization of this study could be possible, because readers could experience for themselves what the participants in this study had gone through, by reading and imagining the situations indicated in this study (Kuroe and Fujisawa, 2016).

\section{Data Generation}

In early February 2018, I passed them a note explaining briefly the aim and general information of this research, and also a questionnaire briefly surveying their old days, in advance of interviews. This is because several days may be necessary for them to recall old days and prepare some detailed images of them. Several days later, I passed them a document describing the items which were supposed to be asked during the interview, in order for them to prepare some answers for each question.

Data were generated through semi-structured interviews, following question items, which were described in the document handed to them in advance. However, I also tried to make them speak as comfortably and freely as possible. With their permission, all interviews were recorded digitally, and verbatim transcriptions were made. The interview was conducted on February 6, 2018, for Mrs. A and on February 11, 2018, for Mr. A. Each interview was conducted for about one hour. 


\section{Data Analysis}

Interview data were analyzed using a qualitative descriptive approach, in order to make descriptive summaries in their own terms (Sandelowski, 2000; Gregg et al., 2013; Gregg et al., 2016). Verbatim transcriptions of digitally recorded interviews were carefully read, and each sentence was scrutinized and then coded. All codes were examined and compared among them for similarities and differences, and sorted into sub-categories. These subcategories were examined and compared among them for similarities and differences to extract categories.

Later, a medium on which the interview for each participant was recorded (a CD or a USB memory), a verbatim transcription, and a qualitative descriptive summary for the interview were handed over to each of the participants, in order to look back upon the interview and confirm what was told during the interview.

All the interviews were originally performed in Japanese, so that data analyses were conducted using verbatim transcriptions written in Japanese. In drafting the manuscript, results were translated into English in an attempt to reflect what they told in the interviews as faithfully as possible.

\section{Ethical Considerations}

First of all, as a certified care-manager and a certified care-worker, I obeyed the following Japanese laws: Articles 69-34 (Obligations of a Long-term Care Support Specialist), 69-36 (Prohibition of Acts to Damage Impartiality), and 69-37 (Confidentiality Obligations, etc.) ofLongTermCareInsuranceAct(http:/ / www.japanlawtranslations.go.jp/law/detail/?id=9 $4 \& v m=\& r e=\& n e w=1$; accessed on August 7, 2020), and Articles 45 (Prohibition of Acts that Damage Credibility), 46 (Duty of Confidentiality), and 47-2 (Responsibility of Quality Improvement) of Certified Social Worker and Certified Care Worker Act (http:/ / www.japaneselawtranslations.go.jp/law /detail $/$ ?id=2693\&vm=04\&re=01\&new= 1; accessed on August 7, 2020). Based upon these laws, I was provided signed informed consent from each of the two participants. The consent form included the aim and brief descriptions of this project, research procedures, their right for withdrawal, and obligation of confidentiality. Especially, in order for the participants not to be identified, some of the contents of the interviews, including personal information, were concealed.

\section{RESULTS}

It was four times that Mr. and Mrs. A had been involved in caring for their own parents and parents-in-law, respectively, at various points in their life courses and in various forms (see METHODOLOGY). In this sense, Mr. and Mrs. A are thought of as highly suitable for this study. Based on their responses expressed in the questionnaire, several questions concerning their experiences of caring for their parents as well as their preferences and wishes in their later lives were prepared. Prior to the interviews, a document mentioning these questions was passed to them. The interviews were performed in accordance with the questions listed, but at the same time I tried to make them talk as frankly and freely as possible.

In the following sections, what each of the participants said about their experiences of caring for his/her parents as well as his/her preferences and wishes for his/her own later life was described respectively.

Mrs. A's Experiences of Caring for Her Parents 
The qualitative descriptive summary concerning the interview conducted for Mrs. A was indicated in Table 1-1 4.

Her father had been bedridden without consciousness after brain tumor surgery. Her mother had dedicated herself to taking care of him, and Mrs. A had visited her parents in hospital a few times a month. Because Mrs. A had a deep affection for her father, she showed complex feelings concerning her father who had kept bedridden, maybe with or without his consciousness (Table 1-1).

"...although I am sure it would have been tough for him if he recognized his own state, he might have recognized it and grieved at his appearance. In fact, when we took care of him and tried to change his diaper, as I told before, he expressed his reluctance, by crossing his legs tightly. Sure enough, he was ashamed of being taken care of by his children, but he became unconscious of such things soon."

Mrs. A cared for her mother-in-law, the relationship with whom was typical of that between a wife and a mother-in-law. Her mother-in-law suffered from dementia, and as her symptoms got worse, including behavioral and psychological symptoms of dementia and delirium at night, she was finally admitted to a nursing facility for the elderly. Until her admission to the nursing facility, Mrs. A, together with Mr. A, took care of her at home, and had severe experiences of caring for the older person with dementia.

"...she had already suffered from dementia. She spoke ill of others, she said she was going to [her neighbor], and so on. At that time, she said she was leaving home, but we couldn't say 'please yourself,' because she would get lost. Therefore, I said 'Please do not go out,' but she had physical strength, and thick arms. In fact,....we struggled with each other, with holding each other's arms. I have had such kinds of experiences several times..."

It was really a tough time for Mrs. A to take care of her mother-in-law at home. However, as Mrs. A visited the nursing home to meet her mother-in-law, she came to feel pity for her for suffering dementia. Mrs. A did not just feel ambiguously reluctant to be senile, but mentioned her acceptance of becoming senile as human fate (Table 1-3). Experiences of caring for her mother-in-law with dementia seem to have made it possible for Mrs. A to envisage concretely her future in which care and help from others would be necessary.

Mrs. A described her experiences of taking care of four parents of hers, two her own and two her parents-in-law, each of which was quite individual but also really valuable. When I asked her about her own future, Mrs. A responded as follows (Table 1-4).

"...during the short time that is left till I suffer from dementia, well, I would like to keep doing my favorite things, such as my hobbies, housework, and whatever I could do, even though it would be only a little...If I have to do these matters, and if I try them very hard, it may be of a little help for preventing dementia...during the time when I can do a set of things, if I do them by myself, it may prevent dementia from getting worse, hopefully. I would like to, even though it would be only a little." 
It seems that the way of life of her mother had a considerable influence on her view of her own later life (Table 1-2 and 4). In fact, she mentioned her mother's influence as follows:

"This is because I have learned from the ways Mother lived, I am sure that, because I watched her being always decent in such ways...Well, although such things are pretty ordinary, people would really cease doing so, because it is so much hassle. There would have been no problem even though she did not do so, but she lived everyday life decently. She kept her appearance straight, kind of. Well, that is because I watched Mother live in such ways, isn't it?"

When I asked Mrs. A what kind of world she would live in, if she were to suffer from dementia, she said that she would have to experience it, but she nevertheless responded as follows (Table 1-4):

"In my case, I would return to my old days when I struggled to raise my children, rather than in my childhood, because I really had a hard time."

Of course, it would be difficult to know of what kind of world we would live in, until we suffer from dementia. However, the old days when she struggled to raise her children have a special meaning for her, so that this should be kept in mind, at least as background information, when her care-plan is considered.

Based on these interview data and qualitative descriptive analyses (Table 1), Mrs. A's preferences and wishes for her later life emerged as in the next section.

\section{Mrs. A's Preferences and Wishes for Her Later Life}

Using [categories] and ((sub-categories)), which emerged from the qualitative data analysis (Table 1-4), Mrs. A's preferences and wishes for her later life were summarized as follows:

[Mother was decent till her end]; ((she lived everyday life decently by herself)) and ((always maintained her appearance)). ((If I do my housework very hard, it may prevent progress in dementia)). ((I would like to keep doing my housework as long as possible, because I always watched Mother working very hard till her end)). ((Even if I need care and help from others, I would like to keep doing what I can do as long as possible)).

Until now, I have been very busy with family affairs and so on, so that I could not make close relationships with my neighbors. ((In the future, I would like to live in harmony with my neighbors, having a tea party and so on, if I can afford to do so)). ((Although Mother was conscious till her end, I guess she might have recalled unpleasant memories in her old days)). ((I feel unpleasant regarding later life, in which I recall bad memories or regret things not progressing as I desire)).

((When I struggled to raise my children, there were some marital problems and family affairs, so that I feel I tried hard and did my best during these days)). ((I cannot imagine what I would be like unless I actually suffer from dementia)). Nonetheless, ((if I suffer 
from dementia, I would return to my old days when I struggled to raise my children, rather than in my childhood)). If I suffer from dementia and come to need care and help, I hope everyone could be involved with me keeping these in mind.

From the standpoint of considering her own later life while she is in good health, what she said during the interview indicated her will to play her roles in her later life actively, instead of being pessimistic about her later life. She thought that playing her roles actively could keep her in good health and prevent her from needing care and support. Of course, this cannot be the final version of her preferences and wishes for her later life, so that it would be important for her and her family to find opportunities frequently and to discuss her wishes as well as her health condition repeatedly. That would be a good basis for her later life.

\section{Mr. A's Experiences of Caring for His Parents}

The qualitative descriptive summary concerning the interview conducted for Mr. A was indicated in Table 2.

For Mr. A, his father was very strict, and had authority over him and other children, especially in his childhood (Table 2-1). It was Mr. A's deep regret that he could not pay much attention to his father's health, because they had a distant relationship with each other, and because Mr. A was busy working. He described this as follows.

"...I had never been to meet Father at the hospital room the whole time. I thought there was no problem because Mother had been staying at the hospital and taking care of him all the time. In addition, because at that time I got promoted and just became a section chief or something, I was really busy, so that I could hardly visit him. Hence, that is why I feel such regrets."

A doctor at the hospital suddenly gave him a call and told him that his father had but a halfyear to live. Till his father's end, Mr. A and other children cared for his father for some ten days without sleeping. Mr. A felt that he could care for his father in an ordinary parentchild relationship (Table 2-1).

"...as for nursing Father after his hospitalization, well, without any ill feelings against Father but with such ordinary feelings as those between a parent and his children, we all nursed Father, together with brothers and Mother, though it was in the hospital, attending all the time and, well, caring for him with bedpans, urinary bottles, and so on. Hence, as far as it is concerned, well, I feel I could care for Father in a true parent-child relationship."

On his deathbed, his father was suffering, so that Mr. A wished to make his suffering father have an ice cream, in order to moderate his suffering. However, Mr. A could not carry out his wish, which left him with deep regrets (Table 2-1).

“...because really, how can I say, his mouth looked so dry that I felt pity for that, I wished to make Father have an ice cream and went out of the hospital. There were no such kinds of places around the hospital, you know, no such kinds of shops around, 
so I could not make him have an ice cream. Well, I still remember that..."

On the other hand, Mr. A's mother suffered from dementia, and Mr. A took care of her at home, together with Mrs. A. His mother's symptoms got worse, so that she finally entered a nursing home for the elderly (Table 2-2). They had his mother admitted to a nursing home, and she was taken care of by the staff there, so that at first Mr. A felt duty and obligation towards visiting his mother at the nursing home; however, he mentioned that when he cared for his mother, he could spend the best time with her without ill feelings since he became an adult (Table 2-2).

"...Because we left Mother in a care facility, and she was taken care of by the staff there, we said hello to the staff there and lowered our heads with our appreciation every time we visited there to meet Mother. Then, we went to Mother's room,... and met her and said 'How are you doing?' or something, with smiles on our faces. Otherwise, well, I cleaned her room, and so on, such kinds of which in themselves I had never done before. However, I got used to doing those things gradually, and the fact that I had indeed done those things made myself wonder why..."

That being said, it seems that taking care of his old parent with dementia at home caused Mr. and Mrs. A serious trouble, as well as his mother also experienced sufferings of that she could not make herself understood by people around her. Mr. A mentioned those days when they cared for his mother at home as follows.

"...while Mother was at home,...and while she stayed at a daycare facility as well,... she said that there was a bad guy behind the curtain, or something,... and returned home. Hence, I guess she had never felt secure, or rather never remained calm....Removing such anxiety is certainly more important than whether she was cured of her illness or not, I feel."

Although Mr. A had trouble taking care of his mother with dementia, when he observed his mother becoming steady and calm gradually after admission to a nursing home, he seemed to become not too pessimistic about suffering from dementia himself (Table 2-2). Although there may be of course some anxiety over suffering from dementia, it is likely that experiences of taking care of his old mother with dementia brought him, as well as Mrs. A, to this state. Mr. A mentioned this as follows:

"...I may as well suffer from dementia, or rather be senile, honestly speaking, I sometimes had such kinds of feelings, just a thought. Hence, well, I feel that I never felt pity or such kinds of feelings like that, for Mother..."

Mr. A described his experiences of taking care of four parents of his, two his own and two his parents-in-law. All of his experiences in taking care of his old parents were quite individual but at the same time were difficult for others. When I asked him about his own later life, the preferences and wishes for it emerged from Mr. A as follows (Table 2-4).

“...certainly, certainly, a relaxed time at home, certainly the bed too, well, dying on a bed in hospital, I am sure I don't wish. Hence,....as for life-prolonging treatments, it seems likely that 
what we need to consider is now, somewhat, segmented into many items, so that I think we need to discuss this point a bit...Hence, I am sure, well, I feel it would be the happiest if I could eat what I want to at home and pass away with everyone present on my deathbed..."

As with Mrs. A, when I asked Mr. A to envisage the world where he would live if he suffers from dementia, he said at first that he did not have any idea of it, but he nevertheless responded as follows (Table 2-4):

"What makes me feel the most nostalgic is, after all, my childhood....Although we had the hardest time, I guess the old days at [my old home] would have been the springtime of my life. Or rather, I feel that I could do what I desired to do."

In contrast to Mrs. A, the response of Mr. A to the question was his elementary school days. The difference in response between Mr. and Mrs. A is very interesting, but his elementary school days were, at least, special and of great value to him, which should be taken into account when he needs to be taken care of.

Based on these interview data and qualitative descriptive analyses (Table 2), Mr. A's preferences and wishes for his later life emerged as in the next section.

\section{Mr. A's Preferences and Wishes for His Later Life}

Using [categories] and ((sub-categories)), which emerged from the qualitative data analysis (Table 2-4), Mr. A's preferences and wishes for his later life were summarized as follows:

((When I need care and help from others, how much I could be satisfied with my own life would be the most fundamental matter)). ((Thanks to everyone, I have done what I desired to do)). Among others, ((my elementary school days were the springtime of my life for me, in which we had the hardest time, but I also could do what I desired to do)). Therefore, I think [the world, to which I should go back if I suffer from dementia, might be my elementary school days]. If I suffer from dementia and come to need care and help, I hope everyone could be involved with me keeping these in mind.

(In my terminal phase, I would like to spend a relaxed time at home, not on a bed in hospital, and to pass away with everyone present on my deathbed)). ((Because [overflowing information concerning elderly care] is provided through TV or newspapers, I am at a loss as to what I should know, when I consider care of myself)). Nevertheless, ((I think we need to talk with each other variously about a broad policy concerning life-prolonging treatment on me)) as well as ((about how we should deal with my belongings, such as books and so on)).

First of all, what he said during the interview indicated his satisfaction with his own life, which made him have such a feeling as that he was waiting for Heaven's will (Table 2-4). Then not only did he mention his preferences and wishes for his terminal phase, but he at the same time showed his wishes for discussing these matters with his family. Although he 
is now in good health, it would be helpful for him to have a clear opportunity to discuss his preferences and wishes for his later life with his family, which would lead to the better ACP process in which doctors, nurses, and family caregivers may be involved when he comes to need medical treatments and care from others in the future.

\section{Discussion}

What is meant by care-plans for the elderly in good health? In Japan, care-managers are presumed to play roles in the LTCI system and provide assistance for the elderly who need long-term care support (Watanabe et al., 2013; Hirakawa, 2016), so that making care-plans for the elderly in good health is beyond the scope of the LTCI system, and care-managers must not be directly involved in these activities. If there is any significance of this study, it shows the need for informal social resources, including family members, friends, volunteers, and so on. For example, Mr. A showed his regrets in his care for his father, in which he could not pay much attention to his father's health and could hardly care at all for his father (Table 2-1). If we could make various opportunities for discussing old parents' future care-plans among family members while they are still in good health, it would be of great significance, taking into account that the proportion of the elderly and the cost of the LTCI system will keep increasing in the future (Ministry of Health, Labour and Welfare, 2016). However, in such countries like Japan, where one-elderly-person households and households with only an elderly couple keep increasing (Cabinet Office Japan, FY 2017), how could it be possible for us to discuss old parents' future care-plans while they are still in good health? In fact, a cross-sectional survey conducted for Japanese elderly people showed that the weaker the social network, including family and friends, the lower the tendency to discuss ACP (Miyashita et al., 2019).

There is a hypothesis in evolutionary biology, called the grandmother hypothesis, which is to explain the prolonged post-reproductive lifespan of elderly people (Hawkes et al., 2000). According to this hypothesis, a prolonged post-reproductive lifespan of the elderly, especially old women, evolved in human beings, because this could increase their inclusive fitnesses through contributing to reproductive success of their own offspring (Hawkes, 2004; Lahdenperä et al., 2004). Therefore, broadly speaking, elderly people evolved to make contributions to their younger generations, so that communications between older people and their younger generations should have been essential for humans. Discussing old parents' future care-plans among family members should be therefore relevant to the evolved human characteristics, but it cannot help but conclude that the current situations in Japan may not provide enough opportunities for the elderly as well as younger generations to discuss these matters.

That being said, given that informal social resources, including family members, friends, volunteers, etc., cannot perform medical treatments for the elderly, so that it is essential for them to contact and consult medical professionals, especially as the health of the elderly may vary over time. In such cases, we may need to convey preferences and wishes of the elderly for their later lives to medical professionals. Therefore, it matters to us how much medical professionals, including doctors, nurses, etc., listen to informal social resources, such as family caregivers and volunteers, that is, how much they could acknowledge the activities that are beyond the scope of the LTCI system. For example, Hirakawa and Uemura (2014) emphasized the importance of communications between medical professionals and care-managers but also the difficulties in communications between medical professionals and care-managers, especially non-medical care-managers. They pointed out that there is a 
communication gap between them, to which technical and emotional factors may contribute. If there is such a gap even between professionals, there is probably a much wider gap between medical professionals and informal social resources, such as family caregivers, friends, volunteers, etc. Therefore, this study maintains that communications between medical professionals and informal social resources should be facilitated. However, as the situations created by the coronavirus disease 2019 pandemics have revealed, medical professionals essentially work in extraordinarily stressful conditions (Matsuo et al., 2020). In addition, the formal care staff for the long-term support are anticipated to be in short supply in the future Japan (Cabinet Office Japan, FY 2017). Therefore, medical and care professionals would work essentially in busy and stressful conditions (Hirakawa et al., 2017), so that it would matter how much these professionals could devote their time and energies to informal social resources. In the near future when population aging is progressing further, it will be a serious problem for Japan to make time and space for the professionals to pay attention to informal social resources.

There may be some institutional concerns about continuity of care support. As Malcomson and Bisbee (2009) pointed out, if there is discontinuity among medical professionals, preferences and wishes of the elderly might be less effective. For example, even though an older person may have discussed this matter in detail with his/her primary care provider, if the older person is hospitalized, then what would happen to his/her preferences and wishes? Would the older person need to discuss it with some hospital doctors again, or would the primary care provider convey his/her preferences and wishes to the hospital staff? Although we recognize the importance of frequent communications with medical professionals on this matter, it seems still unclear with what kinds of medical staff we should discuss this. Although the ACP process seems to be uncommon among the elderly at present (Malcomson and Bisbee, 2009; Aw et al., 2012; Hirayama et al., 2017; Miyashita et al., 2019), in the future Japan where population aging would have been progressing further, arrangements for keeping the continuity among medical and care support would be most helpful especially for the elderly.

Even though the elderly are still in good health and do not need medical treatments and care support, if they could discuss their preferences and wishes for their later lives frequently, even with family members, friends, and volunteers, these discussions would be of great help for the elderly when they really need medical treatments and formal care support later. In this sense, it may be of great significance for the elderly to recall their old days when they used to take care of their old parents and to consider by themselves their own later lives when they need care support. At the same time, there may be other topics for the elderly which could provide them with relevant clues for their future, in which they are in need of support. For example, engaging with older persons at a nursing facility for the elderly through voluntary activities would be helpful for creating their own perspectives on their own later lives. Even though it may be difficult to visit a nursing home regularly, it would be worthwhile to do voluntary work in itself.

It would be more and more important than before to motivate everybody in good health to have a better perspective on elderly care by envisaging to some extent his/her own future life when he/she needs care and support from others, not just to be pessimistic about his/her end-of-life stage. For example, Mr. and Mrs. A expressed their feelings about their later lives, such as fear of suffering from dementia and anxiety over being cared for by others, less frequently than might be expected. Rather, in a sense, they seemed to have reached a mental state in which they could accept any fates in their later lives. This seems 
likely to be strongly affected by their experiences that they had difficulties with their caring for their mother with dementia at home, and observing that she spent her later life peacefully in a nursing home and lived out her full life. In order to envisage one's realistic future in which he/she needs care from others, concrete experiences of relevance might be necessary. Nevertheless, realized situations might be apart from what he/she has envisaged, but it could provide readiness for the future at least to some extent, as in the cases of Mr. and Mrs. A, which would make it possible to discuss frequently his/her own future with family, friends, and medical providers. At the same time, through these discussions, younger generations also could generate their own perspectives on elderly care. In this sense, discussing his/her later life with family and friends may not be thought of as a burden on the next generation at all but a significant contribution to them.

\section{CONCLUSION}

In some countries like Japan, where population aging is progressing to a higher level, help from elderly people is suggested to be essential from the evolutionary perspective, such as the grandmother hypothesis (Hawkes et al., 2000) and evolutionary genetic models of elderly care (Miyo, 2017, 2020). Leaving elderly people in the situations where they are just waiting for their death may also be a substantial loss for nations, because that would provide only costs without benefit from their help for younger generations. To be sure, end-of-life care and advance care planning are very important topics especially from the standpoint of human ethics, so that many and various discussions need to be conducted. However, at the same time, everybody also needs to consider how to have a better perspective on elderly care, which makes it possible for him/her to have a better later life even though he/she needs care and support from others.

\section{ACKNOWLEDGEMENT}

I would like to express my sincere appreciation to the study participants for their cooperation and to Professor Brian Charlesworth (University of Edinburgh) for their critical comments on the manuscript. I would like to express my gratitude to the late Emeritus Professor Hirosuke Kawanishi (Chiba University) for showing me his research attitude towards social problems.

\section{REFERENCES}

Aw, D., Hayhoe, B., Smajdor, A., Bowker, L. K., Conroy, S. P. and Myint, P. K. (2012), “Advance care planning and the older patient", QJM, Vol. 105, pp. 225-230.

Cabinet Office Japan (FY2017), "Annual report on the aging society [summary]", available at: https://www8.cao.go.jp/kourei/english/annualreport/2017/2017pdf_e.html (accessed 27 June 2020).

Dening, K. H., Jones, L. and Sampson, E. L. (2013), "Preferences for end-of-life care: a nominal group study of people with dementia and their family carers", Palliative Medicine, Vol. 27 No. 5, pp. 409-417.

Fried, T. R. and O'Leary, J. R. (2008), “Using the experiences of bereaved caregivers to inform patientand caregiver-centered advance care planning", Journal of General Internal Medicine, Vol. 23 No. 10, pp. 1602-1607.

Fried, T. R., O'Leary, J., Ness, P. V. and Fraenkel, L. (2007), “Inconsistency over time in the preferences of older persons with advanced illness for life-sustaining treatment", Journal of the American Geriatrics Society, Vol. 55 No. 7, pp. 1007-1014. 
Gregg, M. F., Asahara, K. and Yokoyama, M. (2016), How to Conduct and Report Qualitative Research: Aiming to be an Expert of Nursing Research, 2nd Edition, Ishiyaku Publishers, Tokyo, Japan (in Japanese).

Gregg, M. F., Wakisaka, T. and Hayashi, C. (2013), “Nurse managers' strategies for the integration of newly graduated nurses into clinical units in Japan: a qualitative exploratory study", The Open Nursing Journal, Vol. 7, pp. 157-164.

Hawkes, K. (2004), “The grandmother effect”, Nature, Vol. 428, pp. 128-129.

Hawkes, K., O'Connell, J. F., Blurton Jones, N. G., Alvarez, H. and Charnov, E. L. (2000), “The grandmother hypothesis and human evolution", in Cronk, L., Chagnon, N. and Irons, W. (Eds.), Adaptation and Human Behavior: an Anthropological Perspective, Routledge, New York, USA, pp. 237-258.

Hirakawa, Y. (2016), "Care manager as a medical information source for elderly people", Medical Research Archives, Vol. 4 No. 5, pp. 1-12.

Hirakawa, Y. and Uemura, K. (2014), "Non-medical care managers' attitudes towards reporting to, contacting, and consulting physicians", Annals of Gerontology and Geriatric Research, Vol. 1 No. 4,1018 .

Hirakawa, Y., Chiang, C. and Aoyama, A. (2017), "A qualitative study on barriers to achieving highquality, community-based integrated dementia care", Journal of Rural Medicine, Vol. 12 No. 1, pp. 28-32.

Hirayama, Y., Otani, T. and Matsushima, M. (2017), “Japanese citizens' attitude toward end-of-life care and advance directives: a qualitative study for members of medical cooperatives", Journal of General and Family Medicine, Vol. 18, pp. 378-385.

Ito, S., Hikichi, H., Murayama, H., Ishimaru, M., Ogata, Y. and Yasunaga, H. (2018), “Association between advanced care management and progression of care needs level in long-term care recipients: retrospective cohort study", JMIR Aging, Vol. 1 No. 2, e11117.

Iwagami, M. and Tamiya, N. (2019), "The long-term care insurance system in Japan: past, present, and future", JMA Journal, Vol. 2 No. 1, pp 67-69.

Kuroe, Y. and Fujisawa, M. (2016), "Discussion on the significance of the case study research and life story interview method in chronic illness", Journal of Gifu College of Nursing, Vol. 16, No. 1, pp. 105-111 (in Japanese).

Lahdenperä, M., Lummaa, V., Helle, S., Tremblay, M. and Russell, A. F. (2004), "Fitness benefits of prolonged post-reproductive lifespan in women", Nature, Vol. 428, pp. 178-181.

Malcomson, H. and Bisbee, S. (2009), "Perspectives of healthy elders on advance care planning", Journal of the American Academy of Nurse Practitioners, Vol. 21 No. 1, pp. 18-23.

Malterud, K., Siersma, V. D. and Guassora, A. D. (2016), "Sample size in qualitative interview studies: guided by information power", Qualitative Health Research, Vol. 26 No. 13, pp. 1753-1760.

Matsuda, S. (2009), "How has the Japanese health system implemented the care management system?", Asian Pacific Journal of Disease Management, Vol. 3 No. 2, pp. 33-38.

Matsuo, T., Kobayashi, D., Taki, F., Sakamoto, F., Uehara, Y., Mori, N. and Fukui, T. (2020), "Prevalence of health care worker burnout during the coronavirus disease 2019 (COVID-19) pandemic in Japan", JAMA Network Open, Vol. 3 No. 8, e2017271.

Ministry of Health, Labour and Welfare, Health and Welfare Bureau for the Elderly, Japan (2016), "Long-term care insurance system of Japan", available at: https://www.mhlw.go.jp/english/policy/care-welfare/care-welfare-elderly/dl/ltcisj_e.pdf (accessed 20 August 2020).

Miyashita,J., Yamamoto, Y., Shimizu, S., Aoki, T., Azuma, T., Takada, T., Hayashi, M., Kimachi, M., Ikenoue, T., Fukuma, S. and Fukuhara, S. (2019), "Association between social networks and discussions regarding advance care planning among Japanese older adults", PLoS ONE, Vol. 14 No. 3, e0213894.

Miyo, T. (2017), "Why do we care for old parents? Evolutionary genetic model of elderly caring", Open Journal of Genetics, Vol. 7 No. 1, pp. 20-39.

Miyo, T. (2020), "Some considerations on care of the elderly, using evolutionary genetic models", World Journal of Advanced Research and Reviews, Vol. 8 No. 2, pp. 189-202. 
Mullick, A., Martin, J. and Sallnow L. (2013), "An introduction to advance care planning in practice", BMJ, Vol. 347, f6064.

Sandelowski, M. (2000), "Whatever happened to qualitative description?", Research in Nursing and Health, Vol. 23, pp. 334-340.

Tokyo Metropolitan Government (2018), "The long-term care insurance system", available at: https://www.fukushihoken.metro.tokyo.lg.jp/english/social/elder.files/Longterm_Care_Insurance_System.pdf (accessed 29 July 2020).

Ubel, P. A., Loewenstein, G., Schwarz, N. and Smith, D. (2005), "Misimagining the unimaginable: the disability paradox and health care decision making", Health Psychology, Vol. 24 No. 4(Suppl.), S57-S62.

Watanabe, M., Yamamoto-Mitani, N., Nishigaki,M., Okamoto, Y., Igarashi, A. and Suzuki, M. (2013), "Care managers' confidence in managing home-based end-of-life care: a cross-sectional study", BMC Geriatrics, Vol. 13, 67.

\section{APPENDIX}

Table 1-1. Memories concerning Father and caring for him (Mrs. A's case)

\begin{tabular}{|c|c|}
\hline Categories & Sub-categories \\
\hline $\begin{array}{l}\text { Affection for } \\
\text { Father }\end{array}$ & I loved Father who was handsome and always decent. \\
\hline \multirow{4}{*}{$\begin{array}{c}\text { Father who took } \\
\text { good care of our } \\
\text { family }\end{array}$} & $\begin{array}{l}\text { Father devoted himself to rehabilitation, including walking and } \\
\text { massage. }\end{array}$ \\
\hline & $\begin{array}{l}\text { Although Father became disabled by brain tumor, he worked very } \\
\text { hard for our family. }\end{array}$ \\
\hline & $\begin{array}{l}\text { Father devoted himself to and took good care of Mother and } \\
\text { children. }\end{array}$ \\
\hline & $\begin{array}{l}\text { If Father could have talked, he would have told us to live in } \\
\text { harmony with each other in our family. }\end{array}$ \\
\hline \multirow{3}{*}{$\begin{array}{l}\text { Father's brain } \\
\text { tumor surgery } \\
\text { and its } \\
\text { aftereffects }\end{array}$} & Father had undergone surgery for a brain tumor twice. \\
\hline & Father always cared about his conditions. \\
\hline & Father always missed his old days in good condition. \\
\hline \multirow{2}{*}{$\begin{array}{l}\text { Sympathy for } \\
\text { Father suffering } \\
\text { with aftereffects }\end{array}$} & It was a pity that his appearance had changed. \\
\hline & $\begin{array}{l}\text { I think that it is only unpleasant to recall good old days having } \\
\text { already passed by. }\end{array}$ \\
\hline \multirow{2}{*}{$\begin{array}{l}\text { Resignation of } \\
\text { Father to being } \\
\text { cared for by } \\
\text { others }\end{array}$} & Father looked unpleasant when he was cared for by others. \\
\hline & $\begin{array}{l}\text { Father may have resigned himself to the fact that he had to be cared } \\
\text { for by others. }\end{array}$ \\
\hline \multirow{3}{*}{$\begin{array}{c}\text { Complex } \\
\text { feelings about } \\
\text { Father being } \\
\text { hospitalized in } \\
\text { an unconscious } \\
\text { state }\end{array}$} & $\begin{array}{l}\text { I think it was good for Father to lose his consciousness and not to } \\
\text { realize his state. }\end{array}$ \\
\hline & $\begin{array}{l}\text { Although Father should have lost his consciousness, I think } \\
\text { somehow he may have recognized what was going on. }\end{array}$ \\
\hline & $\begin{array}{l}\text { I feel pity for Father for being unable to talk till the end, due to the } \\
\text { sputum suction system. }\end{array}$ \\
\hline \multirow{2}{*}{$\begin{array}{l}\text { Regrets for my } \\
\text { deceased Father }\end{array}$} & I wish I could have talked and taken a trip with him. \\
\hline & $\begin{array}{l}\text { I wish I could have been to the hospital more frequently to care for } \\
\text { Father. }\end{array}$ \\
\hline
\end{tabular}




\begin{tabular}{|c|c|}
\hline & I could not go to the hospital frequently for my own family reasons. \\
\hline \multirow{3}{*}{$\begin{array}{c}\text { Relationship } \\
\text { between Father } \\
\text { and other } \\
\text { siblings }\end{array}$} & $\begin{array}{l}\text { My youngest sister and brother grew up with looking at Father not } \\
\text { being in good condition, so that they sometimes resisted him. }\end{array}$ \\
\hline & $\begin{array}{l}\text { Mother worried about the relationship between my youngest sister } \\
\text { and brother and Father. }\end{array}$ \\
\hline & $\begin{array}{l}\text { While Mother went back to her parents' home, my youngest sister } \\
\text { and brother might have taken care of Father. }\end{array}$ \\
\hline $\begin{array}{c}\text { Mother who } \\
\text { could not have } \\
\text { been to take care } \\
\text { of her father at } \\
\text { her parents' } \\
\text { home }\end{array}$ & $\begin{array}{l}\text { Although Mother wished to go to her parents' home to take care of } \\
\text { her father, she could not do it as she desired. }\end{array}$ \\
\hline $\begin{array}{c}\text { Devotion of a } \\
\text { nurse at the } \\
\text { hospital }\end{array}$ & $\begin{array}{l}\text { A nurse who was from the same part of the country as Mother } \\
\text { kindly devoted herself to taking care of Father. }\end{array}$ \\
\hline
\end{tabular}

Table 1-2. Memories concerning Mother and caring for her (Mrs. A's case)

\begin{tabular}{|c|c|}
\hline Categories & Sub-categories \\
\hline \multirow{3}{*}{$\begin{array}{l}\text { Evaluation of Mother as the } \\
\text { same gender }\end{array}$} & $\begin{array}{l}\text { My evaluation of Mother as the same gender was } \\
\text { different from that of Father. }\end{array}$ \\
\hline & My youngest sister sometimes resisted our parents. \\
\hline & $\begin{array}{l}\text { My youngest sister sometimes resisted our parents, but } \\
\text { she also was sympathetic toward them. }\end{array}$ \\
\hline \multirow{2}{*}{ Family ties which we valued } & $\begin{array}{l}\text { We were always together, wherever we might go and } \\
\text { whatever we might do. }\end{array}$ \\
\hline & $\begin{array}{l}\text { We were repeatedly told by parents to live in harmony } \\
\text { with each other among siblings. }\end{array}$ \\
\hline \multirow{4}{*}{$\begin{array}{l}\text { Mother's troubles which I } \\
\text { recognized after I got } \\
\text { married }\end{array}$} & $\begin{array}{l}\text { I recognized Mother's troubles after I got married and } \\
\text { became a mother. }\end{array}$ \\
\hline & $\begin{array}{l}\text { Mother grew up peacefully in the country before she } \\
\text { got married. }\end{array}$ \\
\hline & Father was very strict against Mother in minute detail. \\
\hline & $\begin{array}{l}\text { Mother obeyed Father without complaining to anybody } \\
\text { about him. }\end{array}$ \\
\hline \multirow{2}{*}{$\begin{array}{l}\text { Mother's behavior which } \\
\text { we imitate unknowingly }\end{array}$} & $\begin{array}{l}\text { Mother used to do her housework, sweep fallen leaves } \\
\text { in the garden and do knitting, till the end even with } \\
\text { physical handicaps. }\end{array}$ \\
\hline & $\begin{array}{l}\text { We all her children imitate Mother's behavior } \\
\text { unknowingly. }\end{array}$ \\
\hline \multirow{2}{*}{$\begin{array}{l}\text { Mother's care devoted to } \\
\text { unconscious Father }\end{array}$} & $\begin{array}{l}\text { Mother used to go to the hospital every day to care for } \\
\text { unconscious Father, even though she was physically } \\
\text { and mentally so stressed. }\end{array}$ \\
\hline & $\begin{array}{l}\text { When Father passed away, Mother told me that she was } \\
\text { relieved, even though she got lonely at home. }\end{array}$ \\
\hline
\end{tabular}




\begin{tabular}{|c|l|}
\hline \multirow{2}{*}{$\begin{array}{c}\text { Mother's social } \\
\text { hospitalization }\end{array}$} & $\begin{array}{l}\text { When Father passed away, Mother was shocked for a } \\
\text { while. }\end{array}$ \\
\cline { 2 - 2 } $\begin{array}{c}\text { Mother maintained her consciousness till her end. } \\
\begin{array}{c}\text { Mother who looked lonely } \\
\text { in a hospital room }\end{array}\end{array}$ & $\begin{array}{l}\text { Finally, Mother gave up living alone and decided to be } \\
\text { hospitalized. }\end{array}$ \\
\cline { 2 - 2 } $\begin{array}{c}\text { Mother looked lonely in a hospital room. } \\
\text { Caring for Mother in which } \\
\text { we all her children } \\
\text { cooperated with each other }\end{array}$ & $\begin{array}{l}\text { We took care of Mother, cooperating with other } \\
\text { siblings. }\end{array}$ \\
\cline { 2 - 2 } $\begin{array}{c}\text { My brother quit his job and returned home in order to } \\
\text { take care of Mother. }\end{array}$ \\
\cline { 2 - 2 } $\begin{array}{c}\text { I think Mother was happy because all her children took } \\
\text { care of her in cooperation with each other. }\end{array}$ \\
\hline \multirow{2}{*}{$\begin{array}{c}\text { Regrets for the deceased } \\
\text { Mother }\end{array}$} & $\begin{array}{l}\text { I could henty years have already passed since Mother died. } \\
\text { my own family reason. }\end{array}$ \\
\cline { 2 - 2 } \begin{tabular}{c} 
I wish I could have been gentler and kinder to Mother. \\
\hline
\end{tabular} \\
\hline
\end{tabular}

Table 1-3. Memories concerning parents-in-law and caring for them (Mrs. A's case)

\begin{tabular}{|c|c|}
\hline Categories & Sub-categories \\
\hline \multirow{2}{*}{$\begin{array}{l}\text { Father-in-law who never } \\
\text { showed his weakness even } \\
\text { after his hospitalization }\end{array}$} & $\begin{array}{l}\text { I felt that Father-in-law was a decent and very strict } \\
\text { person. }\end{array}$ \\
\hline & $\begin{array}{l}\text { Father-in-law never showed his weakness, so that he } \\
\text { refused to meet visitors who came to the hospital to } \\
\text { meet him. }\end{array}$ \\
\hline \multirow{2}{*}{$\begin{array}{l}\text { The tense relationship with } \\
\text { Mother-in-law }\end{array}$} & $\begin{array}{l}\text { The relationship with Mother-in-law was typical of that } \\
\text { between a wife and a mother-in-law. }\end{array}$ \\
\hline & $\begin{array}{l}\text { Mother-in-law enjoyed her life without concern for } \\
\text { others. }\end{array}$ \\
\hline \multirow{2}{*}{$\begin{array}{l}\text { Fights with Mother-in-law } \\
\text { with dementia }\end{array}$} & $\begin{array}{l}\text { I wonder if Mother-in-law might have felt helpless after } \\
\text { she suffered from dementia. }\end{array}$ \\
\hline & $\begin{array}{l}\text { I fought with Mother-in-law who had the behavioral } \\
\text { and psychological symptoms of dementia. }\end{array}$ \\
\hline \multirow{2}{*}{$\begin{array}{l}\text { Sympathy towards Mother- } \\
\text { in-law with dementia }\end{array}$} & $\begin{array}{l}\text { Mother-in-law's personality had been changed to } \\
\text { become charming since she suffered from dementia. }\end{array}$ \\
\hline & $\begin{array}{l}\text { I felt pity for Mother-in-law for suffering from } \\
\text { dementia. }\end{array}$ \\
\hline \multirow{2}{*}{$\begin{array}{l}\text { Complex feelings towards } \\
\text { Mother-in-law with } \\
\text { dementia }\end{array}$} & $\begin{array}{l}\text { Mother-in-law hardly recognized what was going on } \\
\text { around her, but she sometimes noticed us just for a } \\
\text { moment. }\end{array}$ \\
\hline & $\begin{array}{l}\text { It might be happy for us to get gradually unconcerned } \\
\text { with what is going on after suffering from dementia. }\end{array}$ \\
\hline
\end{tabular}


Table 1-4. Concerning care of myself (Mrs. A's case)

\begin{tabular}{|c|c|}
\hline Categories & Sub-categories \\
\hline \multirow{4}{*}{$\begin{array}{l}\text { Images of Mother who was } \\
\text { decent till her end }\end{array}$} & Mother lived everyday life decently by herself. \\
\hline & Mother was always decent, maintaining her appearance. \\
\hline & $\begin{array}{l}\text { Mother-in-law might not have done her housework, } \\
\text { because of my existence. }\end{array}$ \\
\hline & $\begin{array}{l}\text { In his last years, Father sometimes developed odd } \\
\text { behavior, maybe because he had surgery on his brain. }\end{array}$ \\
\hline \multirow{2}{*}{$\begin{array}{l}\text { Dementia-preventing } \\
\text { effects by doing my } \\
\text { housework very hard }\end{array}$} & $\begin{array}{l}\text { If I do my housework very hard, it may prevent } \\
\text { progress in dementia. }\end{array}$ \\
\hline & $\begin{array}{l}\text { I would like to keep doing my housework as long as } \\
\text { possible, because I always watched Mother working } \\
\text { very hard till her end. }\end{array}$ \\
\hline $\begin{array}{l}\text { My hope of doing what I } \\
\text { can do as long as possible }\end{array}$ & $\begin{array}{l}\text { Even if I need care and help from others, I would like to } \\
\text { keep doing what I can do as long as possible. }\end{array}$ \\
\hline \multirow{2}{*}{$\begin{array}{l}\text { My hope of living in } \\
\text { harmony with my neighbors }\end{array}$} & $\begin{array}{l}\text { In the future, I would like to live in harmony with my } \\
\text { neighbors, having a tea party and so on. }\end{array}$ \\
\hline & $\begin{array}{l}\text { I have not yet conceived of participating in some local } \\
\text { voluntary work or attending a day-care center for the } \\
\text { elderly. }\end{array}$ \\
\hline \multirow{2}{*}{$\begin{array}{l}\text { My unpleasant feeling } \\
\text { regarding later life, in } \\
\text { which I regret things not } \\
\text { progressing as desired }\end{array}$} & $\begin{array}{l}\text { I feel unpleasant regarding later life, in which I recall } \\
\text { bad memories or regret things not progressing as I } \\
\text { desire. }\end{array}$ \\
\hline & $\begin{array}{l}\text { Although Mother was conscious till her end, I guess she } \\
\text { might have recalled unpleasant memories in her old } \\
\text { days. }\end{array}$ \\
\hline \multirow{3}{*}{$\begin{array}{l}\text { My brilliant days when I } \\
\text { struggled to raise my } \\
\text { children: the world, to } \\
\text { which I should go back if I } \\
\text { suffer from dementia }\end{array}$} & $\begin{array}{l}\text { I cannot imagine what I would be like unless I actually } \\
\text { suffer from dementia. }\end{array}$ \\
\hline & $\begin{array}{l}\text { If I suffer from dementia, I would return to my old days } \\
\text { when I struggled to raise my children, rather than in my } \\
\text { childhood. }\end{array}$ \\
\hline & $\begin{array}{l}\text { I was brought up peacefully, so that there was no } \\
\text { trouble in my childhood. }\end{array}$ \\
\hline \multirow{3}{*}{$\begin{array}{l}\text { My old days when I } \\
\text { struggled to raise my } \\
\text { children }\end{array}$} & $\begin{array}{l}\text { When I struggled to raise my children, there were some } \\
\text { marital problems and family affairs, so that I feel I tried } \\
\text { hard and did my best during these days. }\end{array}$ \\
\hline & $\begin{array}{l}\text { I had some troubles about which I could not consult } \\
\text { someone else. }\end{array}$ \\
\hline & $\begin{array}{l}\text { I had to deal with a lot of conflicts within my family, } \\
\text { especially with Mother-in-law. }\end{array}$ \\
\hline
\end{tabular}


Table 2-1. Memories concerning Father and caring for him (Mr. A's case)

\begin{tabular}{|c|c|}
\hline Categories & Sub-categories \\
\hline \multirow{3}{*}{$\begin{array}{l}\text { Absolute existence of Father } \\
\text { in my childhood }\end{array}$} & Father had authority over us in my childhood. \\
\hline & Father was smart and very strict about study. \\
\hline & $\begin{array}{l}\text { Father drew the line between work and home, so that } \\
\text { he had never brought his job home. }\end{array}$ \\
\hline \multirow{2}{*}{$\begin{array}{l}\text { A distant relationship with } \\
\text { Father because of living } \\
\text { together }\end{array}$} & $\begin{array}{l}\text { The relationship with Father was such that I always } \\
\text { kept an eye upon Father's mood. }\end{array}$ \\
\hline & $\begin{array}{l}\text { Because Father and I lived together, we had a distant } \\
\text { relationship with each other. }\end{array}$ \\
\hline \multirow[b]{2}{*}{ Father's hospitalization } & Father who had lived together was hospitalized. \\
\hline & $\begin{array}{l}\text { I feel that Father had already recognized his serious } \\
\text { state, when he was hospitalized. }\end{array}$ \\
\hline \multirow[b]{2}{*}{$\begin{array}{l}\text { Caring for Father, to which } \\
\text { we devoted ourselves }\end{array}$} & We cared for Father in the hospital. \\
\hline & $\begin{array}{l}\text { We all his family devoted ourselves to caring for } \\
\text { Father in the hospital. }\end{array}$ \\
\hline \multirow{2}{*}{$\begin{array}{l}\text { Feeling that Father would } \\
\text { have been delighted to be } \\
\text { cared for by his children }\end{array}$} & $\begin{array}{l}\text { I feel that care by his children would have made } \\
\text { Father relaxed and delighted. }\end{array}$ \\
\hline & $\begin{array}{l}\text { I feel I cared for Father in an ordinary parent-child } \\
\text { relationship. }\end{array}$ \\
\hline \multirow{3}{*}{$\begin{array}{l}\text { Feeling as a child for Father } \\
\text { who was dying }\end{array}$} & $\begin{array}{l}\text { I broke into tears when I was called away to the } \\
\text { hospital and met Father for the first time in a while. }\end{array}$ \\
\hline & $\begin{array}{l}\text { I regret, although I would like to make Father have an } \\
\text { ice cream on his deathbed, I could not do it because } \\
\text { there was no store around the hospital. }\end{array}$ \\
\hline & $\begin{array}{l}\text { I think it is humanity that makes us wish to moderate } \\
\text { their sufferings when relatives and friends are going } \\
\text { to pass away. }\end{array}$ \\
\hline \multirow{6}{*}{$\begin{array}{l}\text { Regrets concerning my care } \\
\text { for Father }\end{array}$} & I have deep regrets about caring for Father. \\
\hline & $\begin{array}{l}\text { I was very busy at that time, so that I could not visit } \\
\text { Father in the hospital. }\end{array}$ \\
\hline & $\begin{array}{l}\text { I thought Father was all right because he had been } \\
\text { attended by Mother all the time. }\end{array}$ \\
\hline & $\begin{array}{l}\text { The doctor at the hospital gave me a call and told me } \\
\text { that Father had but a few days or months to live. }\end{array}$ \\
\hline & $\begin{array}{l}\text { I would rather have been concerned with Father's } \\
\text { disease at an earlier stage. }\end{array}$ \\
\hline & $\begin{array}{l}\text { I lived with Father, but I, on the contrary, failed to be } \\
\text { sensitive to Father's condition, and so on. }\end{array}$ \\
\hline $\begin{array}{l}\text { The importance of } \\
\text { communication in care for } \\
\text { others }\end{array}$ & $\begin{array}{l}\text { I think it is important to communicate regularly with } \\
\text { each other from the days when we all are in good } \\
\text { condition, even though it is care by relatives. }\end{array}$ \\
\hline $\begin{array}{c}\text { The difficulty in explaining } \\
\text { human emotions }\end{array}$ & ficult for us to explain human emotions. \\
\hline
\end{tabular}


Table 2-2. Memories concerning Mother and caring for her (Mr. A's case)

\begin{tabular}{|c|c|}
\hline Categories & Sub-categories \\
\hline \multirow{3}{*}{$\begin{array}{l}\text { Some ill feelings against } \\
\text { Mother }\end{array}$} & $\begin{array}{l}\text { I could not have been sympathetic towards Mother's } \\
\text { behavior since I became an adult. }\end{array}$ \\
\hline & $\begin{array}{l}\text { Since Mother suffered from dementia with Lewy bodies, } \\
\text { we had unpleasant feelings, because she sometimes woke } \\
\text { us up at midnight, and so on. }\end{array}$ \\
\hline & $\begin{array}{l}\text { Although we spent a hard time after World War II, I had } \\
\text { some ill feelings against Mother in my childhood, too. }\end{array}$ \\
\hline \multirow{3}{*}{$\begin{array}{l}\text { Mother suffering from } \\
\text { dementia with Lewy bodies }\end{array}$} & $\begin{array}{l}\text { I think Mother lived her life ordinarily, without } \\
\text { recognizing that she suffered from dementia. }\end{array}$ \\
\hline & $\begin{array}{l}\text { I think it was good for Mother that everyone around her } \\
\text { accepted the fact that she suffered from dementia and } \\
\text { treated her well. }\end{array}$ \\
\hline & Initially, I wished she could get over dementia. \\
\hline \multirow{2}{*}{$\begin{array}{l}\text { Sympathy and sense of duty } \\
\text { that I initially had towards } \\
\text { Mother with dementia }\end{array}$} & $\begin{array}{l}\text { I felt pity for Mother for entering the facility for the elderly } \\
\text { because of her dementia. }\end{array}$ \\
\hline & $\begin{array}{l}\text { At first I had a sense of duty and obligation towards } \\
\text { visiting Mother at the nursing home. }\end{array}$ \\
\hline \multirow{2}{*}{$\begin{array}{l}\text { The parent-child bond that I } \\
\text { felt during my caring for } \\
\text { Mother }\end{array}$} & $\begin{array}{l}\text { When I cared for Mother, I could spend the best time with } \\
\text { her without any ill feelings since I became an adult. }\end{array}$ \\
\hline & $\begin{array}{l}\text { When I cared for Mother, I felt we were indeed a parent } \\
\text { and a child. }\end{array}$ \\
\hline \multirow{2}{*}{$\begin{array}{l}\text { Care for Mother with } \\
\text { dementia at the nursing home }\end{array}$} & $\begin{array}{l}\text { I was grateful because Mother's condition got better when } \\
\text { she took Chinese medicine following the direction of a } \\
\text { doctor visiting the nursing home. }\end{array}$ \\
\hline & $\begin{array}{l}\text { Because a care-manager at the nursing home took care of } \\
\text { Mother properly, she gradually became steady and calm. }\end{array}$ \\
\hline \multirow{4}{*}{$\begin{array}{c}\text { Mother who passed away on } \\
\text { the next day when she left } \\
\text { hospital }\end{array}$} & $\begin{array}{l}\text { Just before Mother passed away, she was hospitalized } \\
\text { because of pneumonia. }\end{array}$ \\
\hline & $\begin{array}{l}\text { The night when Mother returned to the nursing home } \\
\text { from the hospital, I hesitated to visit her, because I thought } \\
\text { she was all right. }\end{array}$ \\
\hline & Mother died of suffocation the next morning. \\
\hline & $\begin{array}{l}\text { It is regrettable that at that night I did not check the staff } \\
\text { on the night shift and tell them about Mother's condition. }\end{array}$ \\
\hline \multirow{3}{*}{$\begin{array}{l}\text { Mother who lived out her full } \\
\text { life }\end{array}$} & I think Mother lived out her full life. \\
\hline & When Father died, I had a lot of regrets. \\
\hline & Eighty years have already passed since I was born. \\
\hline \multirow{2}{*}{$\begin{array}{l}\text { Feeling that I may as well } \\
\text { suffer from dementia }\end{array}$} & $\begin{array}{l}\text { I did not feel sad about Mother's dementia; in fact, I also } \\
\text { had a feeling that I may as well suffer from dementia. }\end{array}$ \\
\hline & $\begin{array}{l}\text { If we suffer from dementia, we do not have to worry about } \\
\text { death, do we? }\end{array}$ \\
\hline \multirow[t]{2}{*}{ Care at a nursing facility } & $\begin{array}{l}\text { I think there might be a lot of things at nursing facilities, } \\
\text { which make both care-workers and users happy, if } \\
\text { workers do them for users, based upon their } \\
\text { understanding of users. }\end{array}$ \\
\hline & $\begin{array}{l}\text { I think in caring for someone it would be important to } \\
\text { relieve the person of anxieties. }\end{array}$ \\
\hline
\end{tabular}


Table 2-3. Memories concerning Parents-in-law and caring for them (Mr. A's case)

\begin{tabular}{|c|l|}
\hline Categories & \multicolumn{1}{c|}{ Sub-categories } \\
\hline \multirow{2}{*}{$\begin{array}{c}\text { Father-in-law who was my } \\
\text { boss as well as my great } \\
\text { senior in my company }\end{array}$} & $\begin{array}{c}\text { Father-in-law was my boss as well as my great senior in } \\
\text { my company. }\end{array}$ \\
\cline { 2 - 2 } $\begin{array}{c}\text { Father-in-law who was } \\
\text { about my job and so on. }\end{array}$ \\
\cline { 2 - 2 } $\begin{array}{c}\text { Father-in-law might have been worried about my career. } \\
\text { hospitalized and bedridden }\end{array}$ & $\begin{array}{l}\text { I was present at his hospitalization and his surgery, and } \\
\text { visited him in the hospital. }\end{array}$ \\
\cline { 2 - 2 } $\begin{array}{c}\text { Mother-in-law who took care } \\
\text { of bedridden Father-in-law } \\
\text { for a long time }\end{array}$ & $\begin{array}{l}\text { I admired Mother-in-law for having taken care of } \\
\text { long time }\end{array}$ \\
\hline \multirow{2}{*}{$\begin{array}{c}\text { Decent sisters- and brother- } \\
\text { in-law }\end{array}$} & $\begin{array}{l}\text { I think sisters- and a brother-in-law live their lives } \\
\text { decently, so that parents-in-law would be relaxed up } \\
\text { above. }\end{array}$ \\
\hline
\end{tabular}

Table 2-4. Concerning care of myself (Mr. A's case)

\begin{tabular}{|c|c|}
\hline Categories & Sub-categories \\
\hline \multirow{3}{*}{$\begin{array}{l}\text { My life, in which I have done } \\
\text { what I desired to do }\end{array}$} & $\begin{array}{l}\text { When I need care and help from others, how much I could } \\
\text { be satisfied with my own life would be the most } \\
\text { fundamental matter. }\end{array}$ \\
\hline & Thanks to everyone, I have done what I desired to do. \\
\hline & $\begin{array}{l}\text { I have already lived longer than the mean longevity, so } \\
\text { that I feel I am waiting for Heaven's will. }\end{array}$ \\
\hline \multirow{3}{*}{$\begin{array}{l}\text { My brilliant elementary } \\
\text { school days: the world, to } \\
\text { which I should go back if I } \\
\text { suffer from dementia. }\end{array}$} & $\begin{array}{l}\text { I have no idea of what kind of world I would live in if I } \\
\text { suffer from dementia. }\end{array}$ \\
\hline & $\begin{array}{l}\text { My elementary school days were the springtime of my life } \\
\text { for me, in which we had the hardest time, but I also could } \\
\text { do what I desired to do. }\end{array}$ \\
\hline & $\begin{array}{l}\text { Because the days when I worked for a company are too } \\
\text { realistic, I do not think I would go back to those days if I } \\
\text { suffer from dementia. }\end{array}$ \\
\hline \multirow[b]{2}{*}{$\begin{array}{l}\text { My wish that I would pass } \\
\text { away at home with everyone } \\
\text { present on my deathbed }\end{array}$} & Hopefully, I would like to pass away earlier than my wife. \\
\hline & $\begin{array}{l}\text { In my terminal phase, I would like to spend a relaxed time } \\
\text { at home, not on a bed in hospital, and to pass away with } \\
\text { everyone present on my deathbed. }\end{array}$ \\
\hline $\begin{array}{l}\text { Overflowing information } \\
\text { concerning elderly caring }\end{array}$ & $\begin{array}{l}\text { Because overflowing information is provided through TV } \\
\text { or newspapers, I am at a loss as to what I should know, } \\
\text { when I consider care of myself. }\end{array}$ \\
\hline $\begin{array}{l}\text { The necessity of talking with } \\
\text { each other about life- } \\
\text { prolonging treatment on me }\end{array}$ & $\begin{array}{l}\text { I think we need to talk with each other about a broad } \\
\text { policy concerning life-prolonging treatments on me. }\end{array}$ \\
\hline $\begin{array}{l}\text { The necessity of talking with } \\
\text { each other about the } \\
\text { treatment of my belongings }\end{array}$ & $\begin{array}{l}\text { I think we also need to talk with each other variously } \\
\text { about how we should deal with my belongings, such as } \\
\text { books and so on. }\end{array}$ \\
\hline
\end{tabular}

$$
\text { --0-- }
$$

